\title{
Ectopic thyroid tissue in adrenal gland, case report and review of literature
}

\author{
Ivan Paunovic ${ }^{1,2}$, Branislav Rovcanin ${ }^{1}$, Milan Jovanovic ${ }^{1}$, Matija Buzejic ${ }^{1}$, Dusko Dundjerovic ${ }^{3}$, \\ Vladan Zivaljevic ${ }^{1,2}$
}

${ }^{1}$ Center for Endocrine surgery, Clinical Center of Serbia, Belgrade, Serbia; ${ }^{2}$ School of Medicine, University of Belgrade, Belgrade, Serbia; ${ }^{3}$ Institute for Pathology, School of Medicine, University of Belgrade, Belgrade, Serbia

Correspondence to: Matija Buzejic. Center for Endocrine surgery, Clinical Center of Serbia, Vitanovacka 1, Belgrade, Serbia.

Email: matijabuzejic@gmail.com.

\begin{abstract}
Ectopic thyroid tissue is a rare pathological finding bellow the diaphragm and extremely rare finding is ectopic thyroid tissue in the adrenal gland (ETTAG). Thyroid tissue can be located anywhere along the way of embryological migration pathway of thyroglossal duct. In most cases of ectopic thyroid tissue, it is located in the neck. Here we present a case of 29 years old patient that was laparoscopically operated because of adrenal incidentaloma which showed $28 \mathrm{~mm}$ in maximal diameter on MRI. The patient had normal adrenal function. Pathohistological finding confirmed ETTAG. Follicular cells express TTF-1, Thyroglobulin, PAX8, and cytokeratin 7 , and lack expression of calretinin. This is the 15 th such case described in literature. Women are much more affected than men (14:1), and it usually presents in the fifth decade (mean age 49). In all cases ETTAG was composed of normal follicular cells, and C cells were not found. Review of the literature reveals that adrenal ectopic thyroid tissue is almost always cystic, and has distinctive pathologic features. The most important thing is that ETTAG must be distinguished from metastatic deposits from thyroid gland carcinoma. Our patient had normal thyroid function, without any nodules in thyroid gland. We report the youngest patient with ectopic thyroid tissue located in the adrenal gland.
\end{abstract}

Keywords: Ectopic thyroid tissue; adrenal gland; thyroid; case report

Submitted Apr 24, 2020. Accepted for publication Sep 04, 2020.

doi: $10.21037 /$ gs-20-471

View this article at: http://dx.doi.org/10.21037/gs-20-471

\section{Introduction}

Abnormality of thyroid tissue during embryogenesis, along the passage of thyroglossal duct (from the floor of the primitive foregut to its final location), can cause ectopic thyroid tissue in the neck. Most of the cases are asymptomatic, and symptoms can be caused by tumor size and its relationship with surrounding tissues (1). Diseases affecting the thyroid may also affect the ectopic thyroid. The occurrence of ectopic thyroid tissue is unknown due to unrecognized cases that are often asymptomatic. As mentioned, most of the ectopic thyroid cases are detected in sublingual position along the descending pathway of thyroglossal duct. It is difficult to understand how ectopic thyroid tissue may occur in the thoracic cavity, duodenum, gallbladder, pancreas, ovaries and adrenals (2-7). Extremely rare cases of ectopic thyroid tissue in the adrenal were described before in 14 patients to the best of our knowledge (8-19). The frequency of incidental adrenal tumors on computed tomography (CT) scans is approximately $0.4-4.4 \%$, and in autopsy series incidence of $8.7 \%$ has been reported (20). We present the following article in accordance with the CARE reporting checklist (available at http://dx.doi.org/10.21037/gs-20-471).

\section{Case presentation}

A 29-year-old female was admitted to our clinic for the operation of left adrenal incidentaloma discovered on MRI in October 2019. She was evaluated by her endocrinologist 


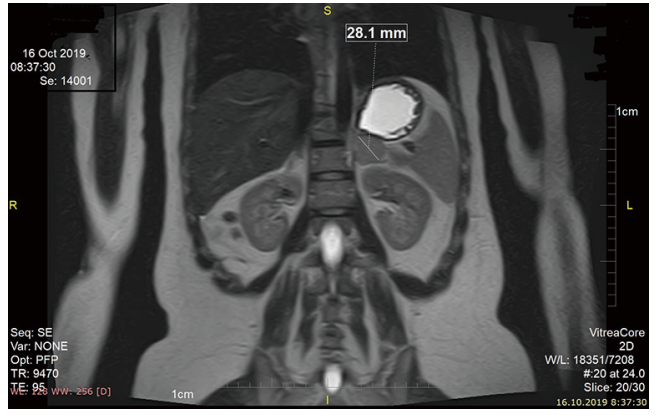

Figure 1 Well-circumscribed multilocular cystic mass $28 \mathrm{~mm}$ in maximal diameter.

because of irregular menstrual cycle for few months. She had no positive family history for tumor, genetic history and psychosocial history. She reported no back pain. Physical examination showed no organomegaly in the abdomen. Ultrasound of abdomen was indicated which revealed cystic mass on the left adrenal. Soon after magnetic resonance imaging (MRI) was performed which showed $24 \mathrm{~mm} \times 25 \mathrm{~mm} \times 28 \mathrm{~mm}$ big lesion, hypointense on T1w and isointense on T2w in left adrenal (Figures 1,2). The patient had normal adrenal function, her cortisol level was $192 \mathrm{nmol} / \mathrm{L}$, adrenaline was $4.6 \mu \mathrm{g} / 24 \mathrm{~h}$, and dopamine was $349 \mu \mathrm{g} / 24 \mathrm{~h}$.

Operation was indicated due to patient's age and the size of lesion. Left laparoscopic adrenalectomy was performed on the $24^{\text {th }}$ of October 2019. Postoperative course was uneventful, and patient was discharged from clinic second day after surgery. Two weeks after surgery pathohistological finding revealed left adrenal gland which dimensions were $40 \mathrm{~mm} \times 20 \mathrm{~mm} \times 4 \mathrm{~mm}$, mass $6.5 \mathrm{~g}$, containing cystic tumor with maximal diameter of $15 \mathrm{~mm}$.

\section{Microscopic findings}

Adrenal gland tissue containing cystic formation with wall composed mostly of one layered cuboidal epithelium under which proliferate follicles composed of cuboidal cells enclosing pink proteinaceous material. The previously described finding was completely consisted of thyroid tissue composed of normal follicles fulfilled with inactive colloid. Follicular cells express TTF-1, Thyroglobulin, PAX8, and cytokeratin 7, and lack expression of calretinin (Figure 3). As soon as we got pathohistological finding we decided to perform ultrasound (US) of the neck. US revealed normal thyroid without any nodes,

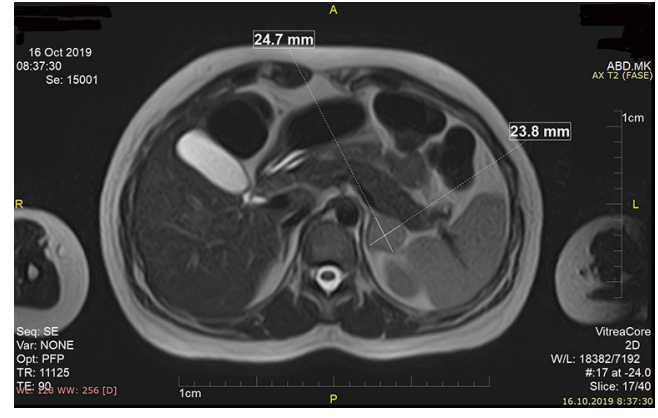

Figure 2 Isointense lesion on T2w in left adrenal $24.7 \mathrm{~mm} \times$ $23.8 \mathrm{~mm}$.

thyroid hormones levels were within physiological range (FT4-11.54 mmol/L, TSH-2.16 mmol/L). Thyroglobulin was $18 \mathrm{mg} / \mathrm{L}$. Six months after operation laboratory studies and US showed normal thyroid status. A timeline of our case show the whole medical procedure (Figure 4). All procedures performed in this study involving human participants were in accordance with the ethical standards of the institutional committee, and with the Helsinki Declaration (as revised in 2013). Written informed consent was obtained from the patient for publication for this case report and any accompanying images. Local institutional Ethical Committee approved the study by decision No. 1575/7. A copy of the written consent was provided for review to the Editor-in-Chief of this journal.

\section{Discussion}

When thyroid tissue is found somewhere outside of the thyroid gland we must think of two things: ectopic thyroid tissue or thyroid carcinoma metastases. Embryologically it is demanding to provide an explanation for presence of ectopic thyroid tissue in the adrenal gland (ETTAG). During the fourth embryonic week thyroid tissue starts to develop from endoderm, and it appears in the floor of the pharyngeal gut. Between fourth and sixth week the diverticulum descends in the midline, from the foramen cecum to its final location of the gland, anterior of trachea (1). Along this route thyroid tissue may fail to migrate properly, and that's how ectopic thyroid can occur. Also ectopic thyroid tissue can be found in subdiaphragmatic organs, such as the gallbladder, ovary, pancreas, duodenum, vagina and the adrenal glands (2-19). Besides this theory of migration, the most uncommon thing is that adrenal is composed of medulla which is ectodermic in origin, and cortex which arise from mesoderm. So 

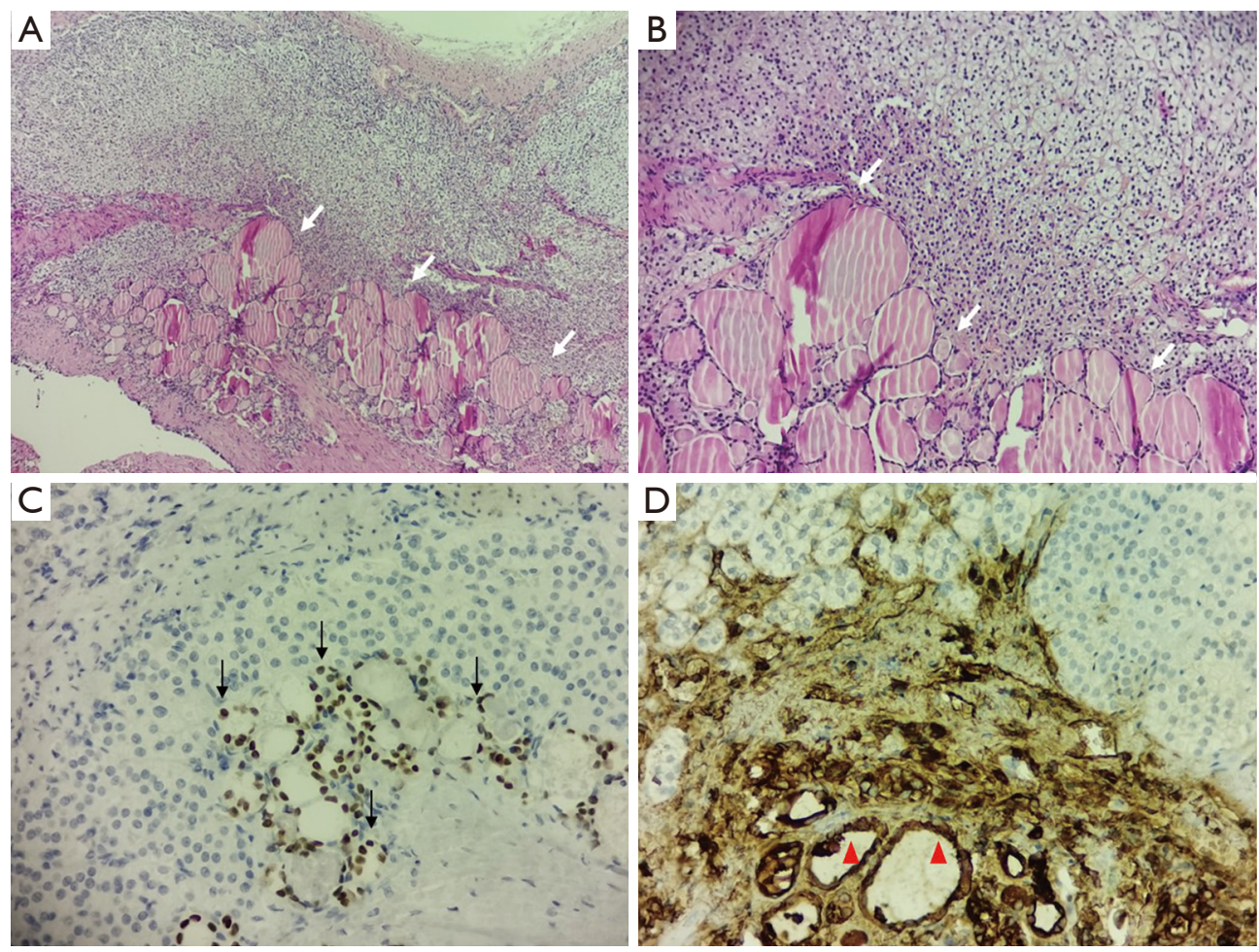

Figure 3 Microscopic finding. (A,B) Thyroid follicles (white arrows) (HE staining, 4x, 10x respectively); (C) TTF1 is expressed in nuclei of follicular cells (black arrows) (20×, TTF1 staining); (D) cytoplasmic expression is apparent in follicular cells (red arrowheads) (20×, thyroglobulin staining).

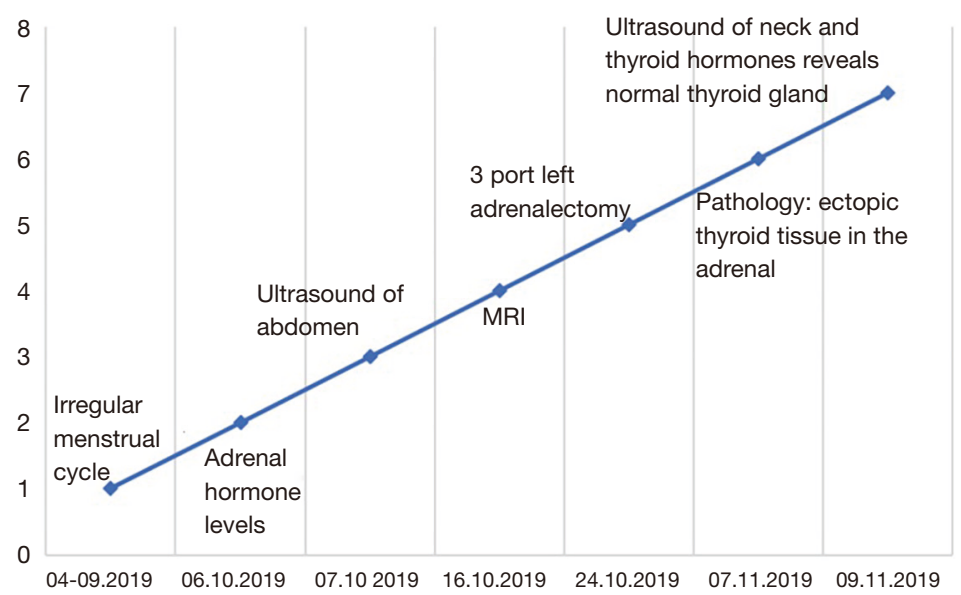

Figure 4 Important date and times in our case.

another explanation may be metaplasia, teratoma, or tumor originating from adrenal stem cells (21). Also an ovarian goiter in females, may be a potential source of ectopic thyroid tissue (5).
To the best of our knowledge this is 13 th case report on this topic, and 15 patients were presented including ours (Table 1). Patients were mostly women (14:1). The median age was 49.86 years, ranging from 29 to 67 years old. Our 
Table 1 Reported cases of ectopic thyroid tissue in the adrenal

\begin{tabular}{|c|c|c|c|c|c|}
\hline Author & Year of publication & Age/Sex & Presentation/hormone status & Pathology finding & Comorbidities \\
\hline \multirow[t]{2}{*}{ Shiraishi (9) } & 1999 & $50 / \mathrm{W}$ & Hypochondrial pain; NF & Right, cystic, $30 \mathrm{~mm}$ & - \\
\hline & & $51 / \mathrm{M}$ & Incidental; / & Right cystic, / & Steatosis hepatis \\
\hline Shuno (10) & 2006 & $50 / \mathrm{W}$ & Preoperative CT; NF & Left, cystic, $50 \mathrm{~mm}$ & Gastric cancer \\
\hline Hagiuda (12) & 2006 & $54 / \mathrm{W}$ & Hypertension; Ald ${ }^{\ddagger}$ & Left, $8 \mathrm{~mm}$ & - \\
\hline Bohinc (13) & 2011 & $61 / \mathrm{W}$ & Hypertension; Ald & Left, $8 \mathrm{~mm}$ & $\mathrm{MCP}^{\S}$ \\
\hline \multirow[t]{2}{*}{ Romero-Rojas (14) } & 2013 & $38 / \mathrm{W}$ & Back pain; Ald & Left, cystic $52 \mathrm{~mm}$ & Endometriosis \\
\hline & & $59 / \mathrm{W}$ & Preoperative CT; NF & Left, cystic $40 \mathrm{~mm}$ & Morgagni hernia \\
\hline Yilmaz (17) & 2016 & $57 / \mathrm{W}$ & Incidental; NF & Right, cystic $50 \mathrm{~mm}$ & Multinodular goiter \\
\hline Li (18) & 2017 & $49 / \mathrm{W}$ & Incidental; NF & Left, cystic $20 \mathrm{~mm}$ & - \\
\hline Rawitzer (19) & 2020 & $39 / \mathrm{W}$ & Back pain; NF & Right, cystic $80 \mathrm{~mm}$ & Asthma \\
\hline Our paper & 2020 & $29 / \mathrm{W}$ & Incidental; NF & Left, cystic, $28 \mathrm{~mm}$ & - \\
\hline
\end{tabular}

${ }^{\dagger}$, non functional; ${ }^{\ddagger}$, hyperaldosteronism; ${ }^{\S}$, micropapillary carcinoma.

patient was the youngest, and she was only 29 years old at the time of the operation. Most of adrenal lesions were incidentally discovered by CT or MRI, some of those (three out of thirteen) were discovered during preoperative diagnostic of other organ pathology. Some patients had discomfort or pain in the back $(15,17,19)$. In three patients preoperatively hyperaldosteronism was detected $(13,14,15)$. Size of tumor ranged from 8 to $80 \mathrm{~mm}$. In all cases cystic degeneration either on CT/MRI images either on gross pathology examination was seen. Only two papers presented case series of two patients $(9,14)$.

The most important thing is to exclude metastasis from thyroid carcinoma. Thyroid function and ultrasound of neck revealed normal thyroid function in our patient. Thyroidectomy was performed in one case because of $5 \mathrm{~mm}$, micropapillary carcinoma. Pathohistological examination and immunophenotype analysis findings of both micropapillary carcinoma and thyroid tissue in the adrenal gland didn't prove the existence of metastasis in that case (13). In one of the patients near subtotal lobectomy of both sides was done, because of multinodular goiter, 32 years before adrenal surgery. In residual thyroid tissue new nodules arose, but FNA was benign (17). In rest of the cases both hormone levels and thyroid visualization (US, CT) showed no thyroid disfunction. In case of suspicious nodules in thyroid gland (US or by fine needle aspiration biopsy) total thyroidectomy is recommended, and it should be followed up by radioiodine therapy (for ablation of lymph node metastases).

Pathological finding showed benign features in all cases including ours. Thyroglobulin (Tg) and thyroid transcription factor (TTF-1) immunostaining can confirm thyroid differentiation, and Galectin-3 and HBME-1, may point towards malignancy. Testing for BRAF V600E mutation may be of prognostic value. Even though it is high specific for papillary carcinoma, this BRAF mutation is absent in the follicular type of papillary cancer (22). In all reports immunohistochemical finding was positive for $\mathrm{Tg}$, TTF1 was determined and positive in five of cases (8-18). Romero-Rojas et al. and Gourmaud et al. reported that galectin 3 and HBME1 were focally positive in the cystlining cells, but were negative in the follicles $(14,15)$. Using real time-polymerase chain reaction (RT-PCR) RomeroRojas et al. didn't identify mutations in BRAF and KRAS genes in adrenal and in thyroid tissue from both of their patients (14). Casadei et al. proved no BRAF (exon 15), 
N-RAS (exon 3), H-RAS (exon 3), and K-RAS (exon 2 and exon 3) genes mutations, which excluded thyroid malignancy (16).

In conclusion, ectopic thyroid tissue in adrenal gland is a rare pathological finding. It almost always has the form of a cystic lesion that is distinctive enough to be noticed both macroscopically and histologically. The most important thing is to distinguish metastatic thyroid cancer of ETTAG in order to avoid an unnecessary thyroidectomy. Improvements in imaging studies and their interpretation have increased over the past few years, and now when these methods are widely used we can expect higher numbers of incidentalomas, and maybe a greater number of ETTAG. Since ectopic thyroid tissue in the adrenal is a very rare finding, and that our patient had only 29 years at the time of the operation, clinicians should consider this as one possibility of differential diagnosis when incidentaloma presents as a cyst with normal hormonal status.

\section{Acknowledgements}

Funding: None.

\section{Footnote}

Reporting Checklist: The authors have completed the CARE reporting checklist. Available at http://dx.doi.org/10.21037/ gs-20-471

Conflicts of Interest: All authors have completed the ICMJE uniform disclosure form (available at http://dx.doi. org/10.21037/gs-20-471). The authors have no conflicts of interest to declare.

Ethical Statement: The authors are accountable for all aspects of the work in ensuring that questions related to the accuracy or integrity of any part of the work are appropriately investigated and resolved. All procedures performed in this study involving human participants were in accordance with the ethical standards of the institutional committee, and with the Helsinki Declaration (as revised in 2013). Written informed consent was obtained from the patient for publication for this case report and any accompanying images. Local institutional Ethical Committee approved the study by decision No. 1575/7. A copy of the written consent was provided for review to the Editor-in-Chief of this journal.
Open Access Statement: This is an Open Access article distributed in accordance with the Creative Commons Attribution-NonCommercial-NoDerivs 4.0 International License (CC BY-NC-ND 4.0), which permits the noncommercial replication and distribution of the article with the strict proviso that no changes or edits are made and the original work is properly cited (including links to both the formal publication through the relevant DOI and the license). See: https://creativecommons.org/licenses/by-nc-nd/4.0/.

\section{References}

1. Noussios G, Anagnostis P, Goulis DG, et al. Ectopic thyroid tissue: anatomical, clinical, and surgical implications of a rare entity. Eur J Endocrinol 2011;165:375-82.

2. De Felice M, Di Lauro R. Thyroid development and its disorders: genetics and molecular mechanisms. Endocr Rev 2004;25:722-46.

3. Cassol CA, Noria D, Asa SL. Ectopic thyroid tissue within the gall bladder: case report and brief review of the literature. Endocr Pathol 2010;21:263-5.

4. Macleod DH. Struma Ovarii (Thyro-Dermoid). A Note on the Teratomatous Origin. Proc R Soc Med 1932;25:1386-91.

5. Eyüboğlu E, Kapan M, Ipek T, et al. Ectopic thyroid in the abdomen: report of a case. Surg Today 1999;29:472-4.

6. Takahashi T, Ishikura H, Kato H, et al. Ectopic thyroid follicles in the submucosa of the duodenum. Virchows Arch A Pathol Anat Histopathol 1991;418:547-50.

7. Kurman RJ, Prabha AC. Thyroid and parathyroid glands in the vaginal wall: report of a case. Am J Clin Pathol 1973;59:503-7.

8. Tsujimura A, Takaha M, Takayama H, et al. Ectopic thyroid tissue in a cystic adrenal mass. Br J Urol 1996;77:605-6.

9. Shiraishi T, Imai H, Fukutome K, et al. Ectopic thyroid in the adrenal gland. Hum Pathol 1999;30:105-8.

10. Shuno Y, Kobayashi T, Morita K, et al. Ectopic thyroid in the adrenal gland presenting as cystic lesion. Surgery 2006;139:580-2.

11. Takao H, Doi I, Watanabe T. Ectopic thyroid in the adrenal gland: computed tomography findings. J Comput Assist Tomogr 2006;30:221-2.

12. Hagiuda J, Kuroda I, Tsukamoto T, et al. Ectopic thyroid in an adrenal mass: a case report, BMC Urology 2006;6:18.

13. Bohinc BN, Parker JC, Hope WW, et al. Micropapillary thyroid carcinoma and concomitant ectopic thyroid tissue 
in the adrenal gland: metastasis or metaplasia? Thyroid 2011;21:1033-8.

14. Romero-Rojas A, Bella-Cueto MR, Meza-Cabrera IA, et al. Ectopic thyroid tissue in the adrenal gland: a report of two cases with pathogenetic implications. Thyroid 2013;23:1644-50.

15. Gourmaud J, Bongiovanni M, Triponez F, et al. Ectopic thyroid tissue in the adrenal gland. Endocr Pathol 2014;25:353-5.

16. Casadei GP, Bertarelli C, Giorgini E, et al. Ectopic Thyroid Tissue in the Adrenal Gland: Report of a Case. Int J Surg Pathol 2015;23:170-5.

17. Yılmaz BA, Aktürk M, Kan E, et al. Ectopic thyroid in the adrenal presenting as an adrenal incidentaloma. Turk J Endocrinol Metab 2016;20:4.

18. Li H, Chen Q, Zhu Y, et al. Ectopic thyroid tissue in the

Cite this article as: Paunovic I, Rovcanin B, Jovanovic M, Buzejic M, Dundjerovic D, Zivaljevic V. Ectopic thyroid tissue in adrenal gland, case report and review of literature. Gland Surg 2020;9(5):1573-1578. doi: 10.21037/gs-20-471 adrenal gland: a case report with clinical and pathogenetic implications. Int J Clin Exp Pathol 2017;10:8761-4.

19. Rawitzer J, Kapakoglou A, Walz MK, et al. Ektopes Schild drüsengewebe in der Nebenniere. Der Pathologe, 2020;41:177-80.

20. Zeiger M, Thompson G, Duh QY, et al. AACE/ AAES Adrenal Incidentaloma Guidelines. EndocrPract 2009;15:101-3.

21. Bishop E, Eble JN, Cheng L, et al. Adrenal myelolipomas show nonrandom $\mathrm{X}$-chromosome inactivation in hematopoietic elements and fat: support for a clonal origin of myelolipomas. Am J Surg Pathol 2006;30:838-43.

22. Rossi ED, Martini M, Straccia P, et al. Detection of ectopic thyroid remnants: a serious diagnostic dilemma. When molecular biology and immunohistochemistry can solve the problem. Pathol Res Pract 2013;209:59-61. 